\title{
Consolidating the Household across the 1945 Divide
}

In 1952 a draft of the Family and Inheritance Law section of the new Civil Code of the Republic of Korea was unveiled. The new Civil Code was to replace the Borrowed Civil Code (Ǔiyong Minpŏp), the colonial civil laws from the Japanese colonial era, the use of which had been prolonged because of the Korean War (1950-53), which had broken out before a new Civil Code was fully prepared. The 1952 draft prompted an acute debate between those who wanted to reclaim what they considered Korean traditions from alleged "Japanese distortion" and those who saw an opportunity to push Koreans toward progress and gender equality. Chang Hwa-sun was one of those who were disappointed with the lack of a provision for daughter's inheritance in the draft Civil Code. She argued, "When a household head dies, leaving behind inheritance, no matter how smart and fine a daughter he has, just because she is a daughter ... the widow has forced on her a distant nephew [as adopted heir] just because he is of the same lineage [tongsŏng tongbon], and he inherits the family's household headship and property; this leads to contradictions in the love between parent and child, and strife and competition between kin."

The resonance of Chang's statement with colonial-period rhetoric is striking: in fact, it repeats the colonial-era logic that criticized the Korean custom of agnatic adoption, which we examined in chapter 3 , almost to the letter. This is not surprising, considering that Chang was a public intellectual active during wartime. Having been educated in Japan in the early 1930s, she frequently appeared in newspapers and on the radio, lecturing on various family matters such as how to best manage a simple and frugal household during wartime. ${ }^{2}$ Repeating the colonial-period rhetoric about a daughter's inheritance, feminists like Chang argued that the new Civil Code of 
South Korea should install son-in-law adoption (sŏyangja ibyang) as a way to give daughters inheritance rights. Many other commentators, however, considered sonin-law adoption one of the most egregious examples of the "Japanese distortion" of Korean family customs. After much debate, and albeit with significant compromises, son-in-law adoption was installed in the final draft of the Korean Civil Code.

As this example illustrates, there was a striking continuity between wartime and postcolonial reform discourses. Even though there was a strong public renunciation of "Japanese color" (woesaek) in the immediate postcolonial years in South Korea, the influence of colonial rhetoric nonetheless cast a long shadow in the Korean reform discourses of the postcolonial era. The legacy was strongest in the particular reform direction toward creating small families and replacing agnatic kin with daughters as backup heirs, both steps pretty much in line with the family system that the Japanese had been trying to institute in Korea. In other words, postcolonial reforms, while assuming the facade of "anticolonial cleanup," very much continued to be framed in the colonial rhetoric of reform; it can also be said that the familyreform program that began in the colonial period continued its course in the postcolonial period. What is different in the postcolonial years is that the proponents of lineage interests found a stronger voice as the representatives of "tradition" and thus were able to modify key features of the colonial household system. The result was a hybrid of the two family systems, in which Korean families had to comply with the doubly constrictive demands of small families and lineage interests. To understand this trajectory of reform discourses, we need to reexamine the 1940s, which in most previous scholarship has simply been set aside as a "period of darkness [amhŭkki]," a time of forced assimilation and national annihilation. How did the reform discourses of the 1920s and 1930s develop through the 1940s and reemerge in 1950 s South Korea? And how did this continuity influence Korea's postcolonial reforms?

\section{THE 1940 CIVIL ORDINANCES}

The 1940s opened with new Civil Ordinances for Korea, which took effect on February 11, 1940. The date was Foundation Day (Kigensetsu), celebrated to honor the enthronement of the first mythical emperor of Japan and thus chosen to symbolize a new beginning for Koreans as Japanese imperial subjects. ${ }^{3}$ Gov. Gen. Minami Jiro, in the pamphlet Shi seido no kaisetsu: Shi towa nanika, ikani shite sadameruka [Explanation on the (Japanese-style) surname system: What is a surname; how does one choose it?], explained the significance of that particular new policy as the last step in realizing Japan-Korea unity (naisen ittai). ${ }^{4}$ As I have noted before, the assimilation of family laws, and thus the facilitation of marriage and adoption among Koreans and Japanese, was considered a critical component in achieving empire-wide unity. ${ }^{5}$

The 1940 Civil-Ordinances Reform implemented two key measures: the NameChange Policy and the lifting of the ban on nonagnatic adoption in Korea, which enabled son-in-law adoption (muko yōshi). Of these two measures, the Name-Change 
Policy has received more popular attention and been understood as the quintessential emblem of the forced assimilation policies designed to recreate Koreans as "(Japanese) imperial subjects" (kōminka seisaku). Under the policy Koreans had six months to report their new household names. The response rate was very low at first, but by the end of the six months, about three million households, approximately 80 percent of the total number of households, had reported new names. Even if one did not report a new Japanese-style (i.e., two-character) surname, all Korean surnames became household names after the designated six-month term. ${ }^{6}$

Scholarly understanding of the 1940 reform has focused on cultural assimilation aimed at obliterating Korean national identity (minjok malsal). Understanding the 1940 Civil Ordinances as an essential part of the forced assimilation policy that sought to make Koreans into imperial subjects, Miyata Setsuko interprets the Name-Change Policy as a policy to erase distinctions between the Koreans and the Japanese to facilitate their blending in with Japanese soldiers in the military. ${ }^{7}$ With an increasing number of casualties since the war with China began in 1937, the Japanese faced an imminent need to conscript Koreans into the Japanese military. There were several roadblocks to such plans because of the status of colonial Korean subjects within the empire: one was that Koreans lacked representation in the Japanese diet, and another was that they were considered not integrated enough with the Japanese to function seamlessly in a single military unit. Suspect loyalty among colonial subjects was another glaring problem. The late 1930s, therefore, saw a series of legal reforms to incorporate Koreans into the fabric of the Japanese Empire that culminated in the 1940 Civil-Ordinances Reform.

Yet while the Name-Change Policy was part of the wartime assimilation policy to facilitate the mobilization of colonized Koreans, both literally and ideologically, the policy was not necessarily designed to achieve the erasure of distinctions between Koreans and Japanese, but rather to impose integration of the former to the latter. Historian Yang T'ae-ho has pointed out that surname politics had a tradition reaching into the ancient history of Japan, when surnames were important tools for incorporating new subjects into the imperial political structure. Conferring Japanese-style surnames on foreign immigrants was a practice from the era of the Yamato court to the Meiji period, when the emperor conferred new surnames on the Ainu and Okinawan peoples. ${ }^{8}$ Many Koreans, therefore, perceived the new Civil Ordinances as a measure of drastic assimilation, but also one with the potential to promote inclusion of Koreans in the Japanese Empire and equality between Koreans and Japanese. Takashi Fujitani has emphasized the potentially powerful equalizing effects of a forceful assimilation policy, which only a desperate war situation could propel. Fujitani argues that the various wartime policies that Japanese deployed to assimilate Koreans into the Japanese nation were not aimed at making them indistinguishable from Japanese but rather at including them, albeit with distinctions along racial lines, into an "enlarged concept of the Japanese nation."9

The 1940 Civil-Ordinances Reform, therefore, was aimed at facilitating the integration of Koreans into the Japanese Empire, all the while maintaining the 
distinctions between Koreans and Japanese. Given a policy that, in effect, served to maintain Korean differences, family laws continued to function as the arena in which differences were articulated. Korean families were again placed in the forever "waiting room," where they were always on the path to progress, which was always equated with the family customs of Japan. The particular traits that were Japanese and promoted as universally progressive were the small family as realized in the household system structured by the household registry (koseki). ${ }^{10}$ This was increasingly so in wartime, when Japan was trying to break away from the Western norm and push its own path to "modernity." As a result of maintaining the difference between Korean and Japanese family customs, the 1940s was also the time when certain unique (or allegedly unique) traits of Korean family customs became fossilized and naturalized into "tradition." The postcolonial trajectory of family-law reform was shaped by these two discursive forces that emerged in the 1940s that naturalized the following aspects of the Korean family: nuclearization and the particular Korean custom of inheritance.

In the following section, I examine the reform discourses on the Korean family and family laws in the 1940s, which continued to produce Korea-specific reform plans that hovered around expanding daughters' inheritance rights and weakening widow rights. This direction of reforms was promoted not as particularly Japanese but as a natural trend toward universal progress, made better thanks to the Japanese modifications designed to protect the family community and to impede the harms of Western individualism. These reform discourses in colonial Korea, which shared great commonality with wartime Japanese discourses, ended up shaping postcolonial legal reforms in South Korea to a surprising degree. The conflation of specific reforms in the 1940 Civil Ordinances with the inevitable transition toward the small, modern family continued to shape postcolonial legal reforms. The result was that the reforms for expanding women's rights centered around the issue of son-in-law adoption even after 1945.

\section{RESPONSE FROM THE MARGINS}

The impact of the 1940 Civil-Ordinances Reform did not reach all Koreans in the same way, nor to the same degree. In other words, the experience of the 1940 reform cannot be neatly contained in one national or nationalist narrative. One case aptly illustrates how surname customs were not uniformly practiced by all Koreans and how the Name-Change Policy thus affected Koreans differently. The case, from 1942, concerned a eunuch family that tried to adopt an heir to continue the ancestral rites. ${ }^{11}$ As eunuchs could not procreate, the long-standing practice was to adopt young boys from poor families to pass down their occupation as well as the responsibility of ancestral rites. ${ }^{12}$ Since the Office of Eunuchs (Naesibu) was abolished during the Kabo Reforms, no new eunuchs were appointed to palatial positions, but existing eunuchs stayed in the palace and continued to serve the royal family. ${ }^{13}$ But when this particular family decided to adopt an heir in 1923, the family learned to their surprise 
that the adoption would not be acknowledged. The reason was that, according to the Japanese-instituted Civil Ordinances, the eunuch family had to follow the Korean custom of adoption, which banned nonagnatic adoption. The colonial government allowed no provisions for exceptional cases such as eunuchs. Same-surname adoption, it was decided, was the only recognized norm for Koreans. The eunuch family could not register their adoption. Nonetheless, they took in the intended adoptee, Sun-bong, who was three years old at the time, and brought him up in the family.

When the Name-Change Policy lifted the ban on different-surname adoption, the eunuch family jumped at the opportunity. But just as the adoption arrangement was underway, Sun-bong's adoptive father to be, Hong Pong-gŭn, died unexpectedly, on March 29, 1940. Even with the 1940 reform, different-surname adoption was not allowed for posthumous adoption (sahu yangja). Regardless, Oh Kŭng-hwa, Hong Pong-gŭn's adoptive great-grandfather and the household head, proceeded to register the adoption with the local office on October 30, 1940. Kŭng-hwa's daughter-in-law, Pok-dong, was not happy with this arrangement. If it were not for Sun-bong, now with the Japanese given name of Nagayoshi, she would have been next in line for household-head succession as the chongbu, eldest daughter-in-law of the family. When Kŭng-hwa passed away soon after, and Nagayoshi succeeded to the household headship, Pok-dong sued Nagayoshi and his adoptive mother and daughter-in-law for arranging an illegitimate adoption. In her statement she argued, "the plaintiff has the obligation to protect the Harashiro family and continue the household name." Oddly, for a daughter-in-law of a eunuch family, Pok-dong seems to have fully embraced the custom of samesurname adoption. Nagayoshi and other defendants protested that it was nonsense to annul the adoption on the grounds of different surnames, when, in fact, all heirs of the family had been adoptees of different surnames for generations.

In the end, the Chōsen High Court ruled in favor of the adoptee, Nagayoshi. The court produced a convoluted explanation that since the Harashiros were an exception to the custom of adoption in Korea, legitimate adoption for them could be achieved by adopting from families that shared surnames with any of the adopted ancestors. Nagayoshi, by the original name of Yi Sun-bong, coincidentally shared the same surname and lineage seat (Chŏnju Yi-ssi) with his adoptive greatgreat-grandfather. One suspects that the judges at the courts worked out this farfetched explanation to protect the adoptee from what they considered an arbitrary accusation on the part of the adoptive grandmother, Pok-dong.

The Name-Change Policy, it can be said, involved a redefinition and reeducation of what surnames meant in Korea. The policy was not simply about taking a Japanese-style surname with two Chinese characters instead of the more common Korean-style surname with one character. Numerous explanatory essays were published in Japanese and Korean at the time to explain the difference between Korean surnames (K: sŏng; J: sei) and Japanese household names (shi). The writers explained that Korean surnames signified the name of a lineage, while the 


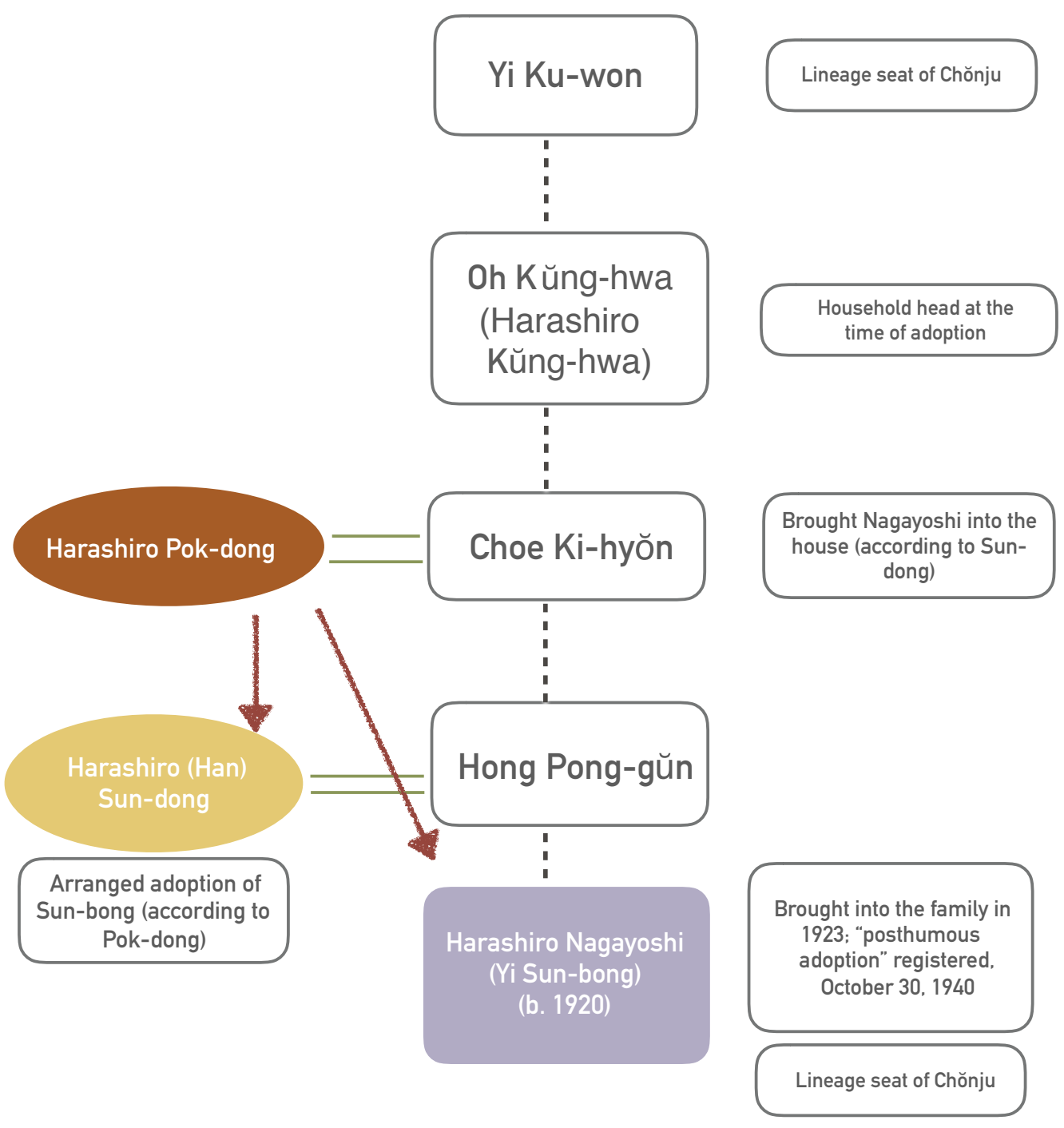

FIGURE 8. A diagram of the Yi Sun-bong case.

Japanese shi signified the name of a household. This was a distinction fabricated in 1940 because sei and shi had been used interchangeably until that point. ${ }^{14}$ With the existing understanding that the lineage system was of the past, and the household system was of the future, the Name-Change Policy thus could be depicted as a policy of progress in the family system. In his pamphlet Gov. Gen. Minami Jirō, indeed, explained that, as times advanced, it was more fit for members of Korean 


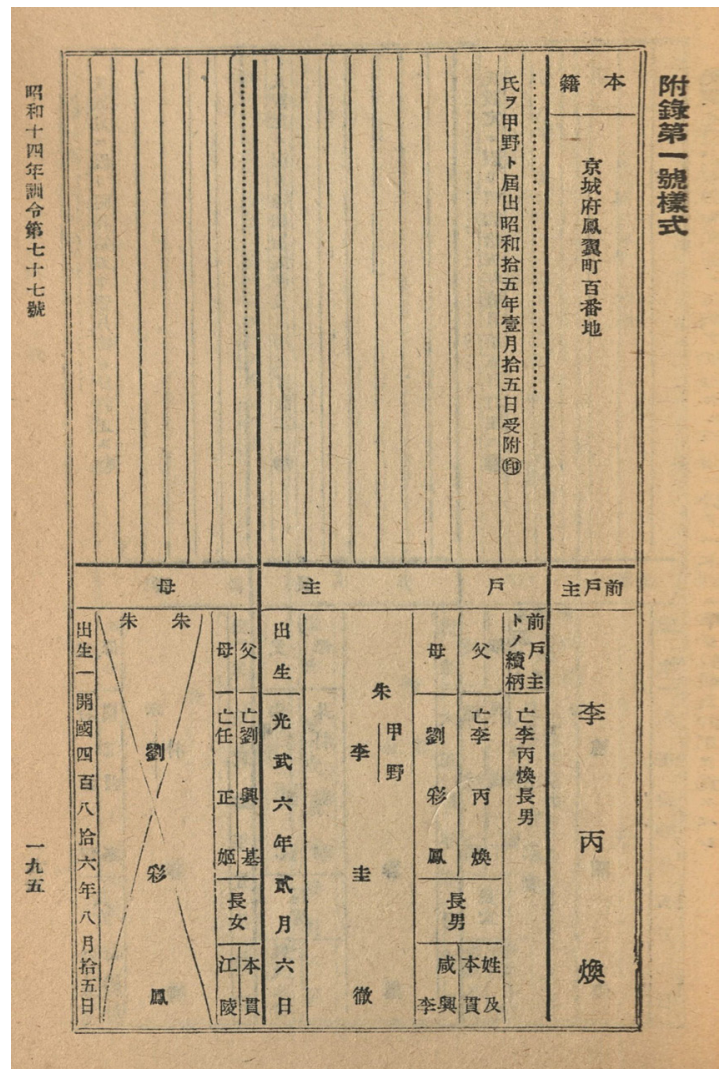

FIGURE 9. An example of name-change documentation. After a name change the original Korean surname would be crossed out but remain visible in the registry. Chōsen Sōtokufu Hōmukyoku, Genkō chōsen koseki hōreishū [Collection of current household registration laws in Korea] (Keijō [Seoul]: Chōsen Koseki Kyōkai, 1942), 195.

households to have names to designate their household. ${ }^{15}$ Both the Japanese and Korean authorities explained the new policy as "adding a household name [shi] to the lineage name [sei]." In fact, Korean surnames were kept in the household registers, and the new household names (Japanese sounding or otherwise) were added to the existing surnames. ${ }^{16}$ In a legal sense, then, it meant choosing a name for the household in addition to (not in place of) the Korean surname.

The Japanese household name also was meant to be shared by all members of the household, which had not been the custom for Koreans. Since all Koreans had to have a household name, regardless of whether or not they reported a "Japanese style surname," all household members ended up bearing the same household name after the Name-Change Policy. This had its most visible impact on married women who hitherto had customarily kept their maiden names. Regardless of whether or not the household chose a new surname, maiden names of married-in women were erased. Helen Kim (aka Kim Hwa-lan), the famous New Woman of Korea and the principal of the Ewha Womans School at the time, pointed to this 


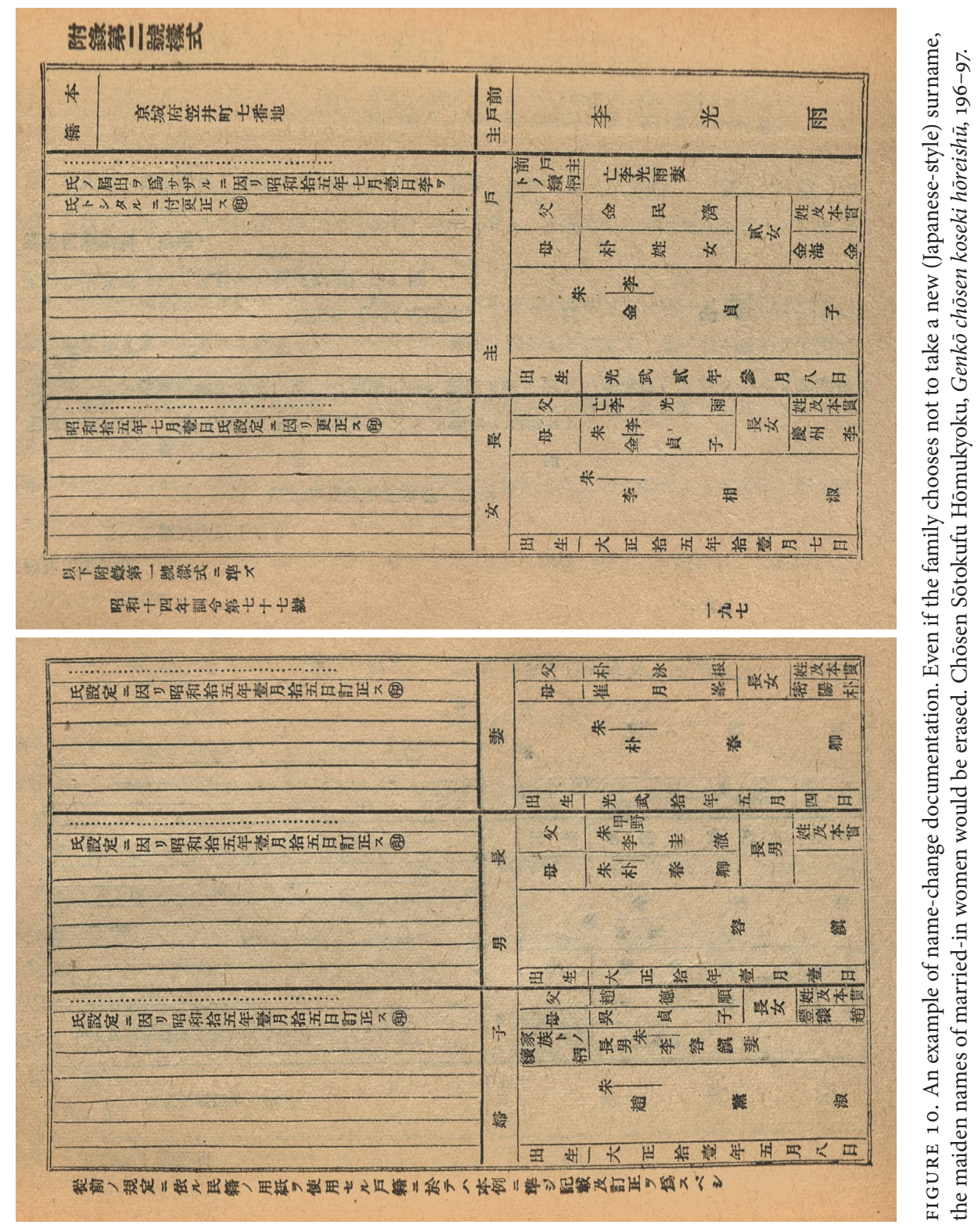


change as a positive one that elevated the married woman's status from that of a child following her father's surname to an equal partner sharing her husband's surname: "One should appreciate this from the perspective of harmony of the home." ${ }^{17}$

Helen Kim herself took the Name-Change Policy as an opportunity to define her own identity through her choice of a new Japanese surname, "Amagi," instead of the name that members of her lineage decided to all take, "Kane'umi" (K: Kimhae), after the name of their lineage seat. Such collective selection of new household names by lineage groups was discouraged by the colonial state and regarded by Koreans as a way of resistance. ${ }^{18}$ The name she chose, Amagi, was more appealing to her because the Chinese characters of the name meant "heaven," a meaningful representation of her Christian identity. ${ }^{19}$ The 1940 Civil-Ordinances Reform allowing-even encouraging-each household head to choose a separate household name independent of the larger lineage enabled Helen Kim and her mother, who was a widowed household head, to choose a different name from the relatives of her father's lineage. Such a move was not one of the intended outcomes of the 1940 reform and, arguably, despite Kim's contention, a woman more commonly lost a piece of her identity when she was forced to replace her maiden name with her husband's name. The case of Helen Kim, nonetheless, shows that some women were able to use the Name-Change Policy to express their independence from the patriarchal family order. Kim's case also can be seen as an outgrowth or continuation of discursive trends from decades prior. Kim's feminist appropriation of the new Civil Ordinances was not merely a single anomaly but a product and reflection of the long strand of thoughts developing since the 1920 s that framed changes in inheritance rights in the colonial household system as an expansion of women's rights.

Helen Kim's ability to turn the Name-Change Policy to her purposes, however, evidences the fact that, despite the apparently benign explanations of officials, the main objective of the Name-Change Policy was to starkly render the distinction of the household from the lineage rather than simply making Korean surnames similar to those of Japanese. In fact, Government General pamphlets recommended that Koreans not take existing Japanese names but instead invent their own based on the names of their hometown or lineage seat. ${ }^{20}$ While the Japanese had to keep their main family's household name when they divided the house (bunke), that is, established a separate household, each household in Korea was encouraged to choose its own name, possibly and preferably different from that of the main branch of the family. It was emphasized that the new surname in Korea was a signifier for the household and not the lineage. Historian Yang T'ae-ho has pointed out that, although the fears of genealogy extinction felt by some Koreans about the 1940 Civil-Ordinances Reform - such as that a family's genealogy record would be abolished-were inaccurate about the policy itself, they were insightful about the potential harm the Name-Change Policy would have on the lineage. ${ }^{21}$ The Name-Change Policy was therefore much larger than an issue of names; it was 
in fact an attempt at structural transformation of the Korean family system itself, a "Japanification of the family system [kazoku seido no nihonka]."22

\section{REFORM DISCOURSES IN THE 1940S}

Exceptional responses to the 1940 Civil-Ordinances Reform illustrate that the impact of the reform cannot be simplified to one result or another. Likewise, the variations among intentions, expectations, and consequences cannot be reduced to simple formulae. The potential for positive benefits of inclusion by way of assimilation was not lost on Koreans and led many cultural nationalists to turn to vociferous support for assimilation measures. Yi Kwang-su, one of the most famous of these cultural nationalists, explained his choice to take a Japanese name with the logic that Koreans would someday achieve equality of status within the Japanese Empire. ${ }^{23}$ Yet efforts to maintain the distinction and differences between Koreans and Japanese continued after 1940. As noted, anxiety about diminishing differences between Koreans and Japanese led the Japanese colonial government to discourage Koreans from choosing existing Japanese names. ${ }^{24}$ When Koreans, as encouraged, created new names from the names of their hometowns or their professions, the resulting names were easily distinguishable from Japanese names. Even without such easily distinguishable names, Koreans were kept separate legally from the Japanese through the separation of household registers. Continued demands (both from Koreans and from Japanese residing in colonial territories) to allow people to move their "original place of registry" (honseki) to different territories of the Japanese Empire were denied, thereby effectively making the distinction between the Japanese and the colonial populations permanent. ${ }^{25}$

Moreover, information about legal, cultural, and customary differences between Japanese and Koreans was continuously disseminated even after the CivilOrdinances Reform supposedly boosted Korean assimilation. In the early 1940 s legal journals in colonial Korea were inundated with articles offering an overview of the history of Korean legal reforms and the differences between the Korean and Japanese legal systems. These articles did more than merely address practical issues about how to treat specific legal matters. As a group, the articles also established narratives about the transformation of family laws in colonial Korea, the nature of the unique customs that remained, what these remaining unique customs said about the nature of Korean society, and how the Japanese colonial rulers - or the writers themselves, as legal authorities in the colony-were to manage this colonial difference. In other words, rather than erasing the differences between Korea and Japan, the so-called forced assimilation of 1940 perpetuated the differences that still remained and their legal significance. In these articles two major differences emerge in striking relief: the lack of daughters' inheritance rights and the continuing inheritance rights of widows in Korea. The bias against daughter's inheritance rights was written into the lineage laws, and partial reforms in the 
inheritance custom were not enough to change that. But, more significant, we see in the 1940s that legal specialists in colonial Korea clearly were approaching this problem of difference (failure of assimilation) less as a temporal problem, that is, a problem owing to Korea's place in the singular trajectory of progress, but more as a matter of local variances that the colonial legal authorities must manage. Through these discourses that highlighted Korean differences, in other words, the Korean customs based on the lineage system became further fossilized as unique Korean traits, and their longevity ironically was strengthened.

Utilizing his extended expertise in family matters, Nomura Chōtarō continued to publish on the characteristics of the Korean lineage system and explained for his readers the continuing differences in Korean family customs that needed to be attended to in adjudicating family cases in Korea. In several articles published after 1940, Nomura expounded on the differences between Korean family law and the Japanese Civil Code, focusing on matters of family laws such as adoption, lineage property, and inheritance. In a 1941 article Nomura focused on Korean inheritance customs, explaining how the Korean concept of inheritance required lineage membership and followed the laws of ancestral rites inheritance (K: chesa sangsok; J: saishi sōzoku). Emphasizing to readers that these differences remained after the 1940 reform, Nomura slightly shifted his previous position from the 1920 s and the 1930 s on reforming ancestor-veneration inheritance. He maintained the position that there should be only two kinds of inheritance in Korea-household-head and property inheritance, just as in the Japanese Civil Code-but now argued that Korea should use the laws of ancestral rites inheritance from the traditional Korean laws of lineage (chongpŏp) as the substantial laws for household-head inheritance among Koreans. At the end of the article, Nomura explained his reasoning: he noted that the division between household-head inheritance and ancestral rites inheritance, which was utilized only when widows became household heads, had created much confusion over the rights of the widowed household heads and had led to much conflict among kin. Nomura noted that even though after the 1940 reform the women of the family (i.e., married-in women) came to also use the same family name, lineage laws that excluded widows from full inheritance still stood. To diminish the confusion and conflicts, Nomura suggested that widow inheritance be given a different term than "inheritance." ${ }^{26}$ In this new age after 1940, Nomura seems to have approached the enterprise of family-law reform as a reform not toward progress but as a practical adjustment to diminish conflict and simplify adjudication processes. ${ }^{27}$ In his view established customs such as lineage laws were to be respected and maintained, and customs less central, such as widow rights, were to be disposed. ${ }^{28}$

Not everyone thought that Korean widow rights were necessarily a backward custom. In "Chōsen ni okeru kafu no sōzokuken [Widows' inheritance rights in Korea]," Judge Yama'uchi Toshihiko compared the difference between widows' rights in Korea and Japan and tried to explain them in terms of the different 
degrees of belief in communal property rights in the two countries. ${ }^{29}$ Unlike many other writers, such as Asami Rintarō, discussed in chapter 3, Yamauchi argued that strong widow rights and the power of testimony in deciding the heir or heiradoptee in Korean customs proved that Korea had a more individualistic take on property ownership. In contrast, weak widow rights in the Japanese Civil Code showed that Japanese property ownership had a stronger foundation in communal ownership. Of course, by the height of wartime in 1940, individualism was no longer a prized marker of progress but a marker of Western modernity that was to be overcome by the traditional virtue of Japanese communalism.

The son-in-law adoptions that became possible in Korea in 1940 also were the focus of detailed analyses of Korean and Japanese differences. In a serialized essay titled "Chōsen minjirei ni okeru muko-yōshi ni tsuite [On son-in-law adoption according to Korean Civil Ordinances]," the head of the Civil Affairs Section in the Legal Division, Iwajima Hajime, gave an overview of son-in-law adoption in colonial Korea and laid out the differences between son-in-law adoption in Korea and Japan. ${ }^{30}$ He noted that, unlike in Japan, an adopted son-in-law in Korea was the presumed heir of the house. In Japan the adopted son-in-law's access to inheritance was determined by his wife's inheritance status. Therefore, if a natural son is born to the parents after the adoption, in Japan the adopted son-in-law lost his heir status, whereas in Korea the adopted son-in-law still had top priority to become the heir. This, the author explained, was owing to the difference in adoption customs between Korea and Japan: adoption in Korea was limited only to adopting an heir, and therefore the adopted son-in-law was "adopted as heir." In contradiction to all the talk at the time about son-in-law adoption expanding a daughter's inheritance rights, he added that the Japanese custom of equating the adopted son-in-law's status to heirship with the daughter's did not make sense in Korea, where daughters did not have the right to inherit the household headship. The author's purpose in citing the difference was less about casting Korean customs in a negative light than about emphasizing the benefits of such customs. The author, for example, noted that Korean son-in-law adoption solved the Japanese problem of the insecure status of adopted sons-in-law. But the author made clear that the lack of daughters' inheritance rights in Korea was a problem that needed to be reformed. Other differences as well, such as the ban on intralineage marriage, he presented in a negative light and in immediate need of reform.

Other unique customs that persisted in Korea also were topics of scholarly attention. In "Dōsei dōhon fukon [The ban on intralineage marriage]," Korean ethnologist Chang Sŭng-du examined the history of the Korean ban on marrying within the same lineage seat and same lineage. After recounting a long list of examples of such a ban from historical texts dating back to the History of the Wei Dynasty (Weizhi) and the Three Kingdoms period (first century BCE to sixth century $\mathrm{CE}$ ), Chang concluded with the observation that, despite the long ban, there were cases where Koreans had married within the lineage. Citing one survey, 
Chang compared numbers from urban and rural areas, showing that the number of marriages within the lineage was higher in urban areas. This, Chang argued, showed that rural areas were more beholden to the old customs. The underlying assumption, of course, was that the old custom of banning marriage within the lineage was backward and irrational and that more enlightened urban residents had managed to free themselves of it. ${ }^{31}$

The works published in the short period between the 1940 Civil-Ordinances Reform and the end of colonial rule in 1945 continued to produce knowledge about Japanese and Korean differences. These pieces of knowledge, as they were not necessarily marked as "Japanese" per se, continued to be disseminated without much alarm in the postcolonial years. The fact that the same Korean scholars, as the few experts on family law in the postwar years, continued to produce similar works did not help to create a clean slate for debates on family customs. Indeed, the long legacy of their works directly influenced the writing of the 1960 Civil Code in South Korea.

\section{THE WRITING OF THE NEW CIVIL CODE}

When Japan, after its surrender, relinquished all of its former colonies, the United States and the Soviet Union separated the Korean Peninsula along the thirtyeighth parallel and began the demilitarization process. On the northern side the Soviet Union immediately annulled all Japanese colonial laws. On the southern side, in contrast, the United States annulled only a portion of the Japanese laws. On October 23, 1946, the 1940 Civil-Ordinances Reform was repealed by U.S. military government's Ordinance 122. Japanese-style names that came into effect through the Name-Change Policy were nullified, and all Korean names were changed back to their original forms. ${ }^{32}$ Those who wanted to retain their Japanese names needed to make a special request to the authorities within sixteen days. As one of the first reform measures undertaken by the U.S. military government, the repeal of the Japanese-surname policy was supposed to signify a symbolic ending of the Japanese colonial distortion of Korean family customs and the beginning of decolonization in Korea.

Not all Koreans agreed that repealing the colonial Civil Ordinances in Korea was a good idea. Kim Tu-hŏn, in his Han'guk kajok chedo yŏngu (Research in the Korean family system), criticized the U.S. policy of repealing the 1940 Civil Ordinances. Kim argued that the repeal, while it abolished the colonial legacy, also did away with the positive features of the law: "The Name-Change Policy was not just implementing Japanese-style names; it also had an aspect of modernizing the Korean family system itself. But the [U.S. policy to repeal the law] did not consider this aspect at all." ${ }_{33}$ In an earlier edition of the book, Kim noted that even though the Name-Change Policy was inspired by the political goal of assimilation, the Korean surname would eventually change from being a marker 
of kinsmen (hyŏljok ch'ingho) to a marker of family (kajok ch'ingho), following the inevitable trend of lineage reduction. ${ }^{34}$ Repeating verbatim his wartime argument (see chapter 3), Kim asserted throughout the book that Korean families had modernized during the colonial period through a process of lineage divisions into smaller nuclear families. A spike in divorce rates and the expansion of women's rights (which also propelled the divorce rate upward) were major and important factors that sped up the process. The 1940 Civil-Ordinances Reform and its policy of household names, Kim pointed out, was another factor that divided the lineage into small families and strengthened the nuclear household.

Apart from the reversal of Japanese surnames, however, all of the colonial civil laws initially were kept intact by the U.S. military government. Ordinance 21, issued November 2, 1945, ordered all Japanese laws to be retained for the practical purpose of sustaining stability for a temporary period, but their use was unexpectedly prolonged because of the Korean War (1950-53). The compilation of the new Civil Code was delayed until 1958 and then came into effect only in 1960. Since Japan replaced its own prewar Civil Code with a new Civil Code in 1948, the prewar Japanese Civil Code had a longer life in Korea. Until the new Civil Code was promulgated, the Borrowed Civil Code (üiyong minpŏp), that is, the colonial law of Civil Ordinances, was used, which meant that family matters still were decided according to Korean customs as defined by the Japanese colonial courts. Thus, the end of Japanese colonial rule brought about little change in the civil-law regime in the immediate postwar period..$^{35}$

With the delayed preparation of the new Civil Code, the effects of the Borrowed Civil Code continued to run long and deep. Thus, civil lawsuits over widows' rights, for example, manifested striking continuity across the 1945 divide. In a case from 1959 , a widow's right to designate an adoptee was challenged. ${ }^{36}$ The narrative of the litigation is now familiar to us: a male relative of the widow, backed by the family council (chinjokhoe), forced an adoption agreement, arguing that the widow had refused to choose an heir for her deceased husband and thereby neglected her obligation. In this case the widow had registered some of the household property under the name of her son from a previous marriage. The widow refused the adoption agreement and argued that only she had the customary right to choose an heir. The Supreme Court confirmed that the widow indeed had the right to choose an heir and just because she did not exercise her right was not sufficient proof that she did not have the intention to choose an heir indefinitely. The family council, therefore, could not designate an adoptee and force the choice on her. This case, even to the very details of the litigants' arguments, was strikingly similar to cases from the colonial period described in chapter 3. What is also notable is the similarity of the format and argument of the decision made by the postliberation Supreme Court to that of the colonial High Court. The Borrowed Civil Code in fact continued to influence civil cases even after the promulgation of the new Civil Code, leading one legal scholar to argue for its abolition as late as $2008 .{ }^{37}$ 
During the time of the new Civil Code's preparation, public anticipation (and anxiety) for a major reform ran high. The so-called Japanese color was to be abolished, it was said, and the tool was to be the newly codified civil law. The family laws in particular were considered a crucial area of decolonization. The problem was that despite the popular perception that postliberation South Korean society had a uniformly negative position against the wartime colonial civil laws, Korea in the immediate postliberation period was quite diversely divided over the direction of the new Civil Code. There was not a consensus over what elements had been Japanese impositions to begin with nor what to do with such a colonial legacy.

Preparation for the new Civil Code began immediately after the new constitution was promulgated in July 1948. The new constitution was based on democratic principles-declaring equal rights for all, including equality of the sexes-with which the civil laws from Japanese colonial rule were deemed incompatible. On September 15, 1948, the Codification Committee (Pŏpchŏn P'yŏnch'an Wiwŏnhoe) was formed to prepare civil, penal, and commercial laws. Legal specialists from all areas were sought to staff the committee.

The process of writing the laws was not smooth. Family law turned out to be especially divisive. Chang Kyŏng-gŭn, one of the committee members, highlighted the special challenges when he published the basic principles of family- and inheritance-law preparation in 1948: "Preparing family and inheritance laws is the most difficult enterprise of all law preparation, as we cannot rely on foreign laws, and there is no consensus among scholars and the public on whether to focus on custom and tradition or progress and reform. ... I have drafted the following principles focusing on maintaining the good and beautiful customs but effecting gradual progress by discarding those feudal evil customs that are uncivilized, illegal, and unfit for present times and that impede our nation from developing in step with the world." ${ }^{38}$

The "gradual progress" that seemed to be a calm and rational approach to what could be a caustic and divisive matter in a still-volatile postwar environment was in fact a veneer over a conservative position to keep most of the laws from the colonial period. This was not surprising, as Chang himself was a legal specialist from the colonial era, a former judge at the Keijō (K: Kyŏngsŏng, i.e., Seoul) local and appellate courts. His understanding of the effects of the laws and their reformative effects on customs was quite similar to the positions of judges' during the colonial period that we have seen in previous chapters. The following statements sound almost the same as those by colonial-era judges and show how many of the ways of thinking from colonial times continued into the postliberation era.

Chang writes in the same essay,

Our current family and inheritance law ... has its basis in the unique East Asian family system, which is centered on not the actual communal unit of living but the larger family [kwangbŏmwi ŭi ka] under the strong authority of the household head [and maintained by] the desire to contain the community that shares common ancestral rites among the male agnatic kin (eldest son or grandson) and therewith continue 
the family [ $k a$, that is, ie in Japanese] without break. This is true to the Confucian rituals and teachings [yugyo ǔi yegyo sasang] and is a beautiful custom from the old [kore üi sunp'ung misok] but also is behind the times when the familial communal unit is transitioning from a large organization that is a production and management unit to the small organization of a consumption unit; from submission of the individual to enlightenment of the individual: the strong control and management of the family system therefore has turned into an evil custom that impedes the growth of the individual [kae'in sinjang]. ${ }^{39}$

Chang's observation that the transition from large to smaller families is natural and inevitable was exactly the same as that made by scholars in the colonial period, in particular Kim Tu-hŏn and Chŏng Kwang-hyŏn. The perception led those two to interpret the 1940 Civil-Ordinances Reform, especially the Name-Change Policy, as an impetus toward a modern family system and a corrective to Korea's lineageoriented family system. Common perceptions and characterizations of the Korean family system on the eve of the liberation carried on into the post-1945 moment and deeply influenced the direction of the postcolonial reforms of the family laws.

Multiple attempts at a consensus on a new Civil Code all went for naught with the outbreak of the Korean War, which led to the death or abduction of many of the committee members as well as the loss of the Chang draft. In the aftermath of the Korean War, the chair of the Codification Committee, Kim Pyŏng-ro, took on the task of writing new family and inheritance laws. Kim had quite a different position from Chang's view of "gradual progress," which essentially meant the maintenance of colonial laws and sharply conflicted with Kim's focus on entirely restoring the good and beautiful customs, that is, returning to the old and traditional ways. Kim himself was a traditionalist and nationalist. Even though he was a Japan-educated former judge and lawyer during the colonial period, he was famous for his work defending Korean nationalists indicted for their activities in pursuit of Korean independence. Many of Kim's statements expose his strong antiJapanese and nationalist sentiments. His adherence to nationalism meant that he considered restoration of what he saw as Korean tradition more important than realizing the constitutional principles of gender equality. In the revised Civil Code, Kim's position translated into restoring strong patriarchal rights of the household head, maintaining the principle of primogeniture in household-head succession, and abolishing son-in-law adoption.

The draft completed in 1952 drew much criticism from legal scholars as well as the public. Chŏng Kwang-hyŏn criticized the new draft for disregarding the original principles laid out in 1948. Yi T'ae-yŏng, the first female lawyer in Korea, criticized the draft for blatantly violating gender equality, and she began a social movement to repeal the proposed draft. Yi and women's groups presented a formal proposal demanding various reforms, including the abolition of the householdhead system itself. They also demanded the repeal of the ban on intralineage marriage. Against such demands from women's groups, the Association of Confucian 
Scholars (Yurim) also organized a strong movement. They fiercely defended the household-head system as the foundation of social order and morality. They also considered intralineage marriages as "barbaric acts, unthinkable for humans." ${ }^{\circ}$ Yi recounted that when she and the leaders of nine women's organizations met with Kim Pyŏng-ro, he severely reprimanded them and declared that he would not change one dot in the draft before he was dead.

Legal experts from the colonial era who had been educated in Japan and worked within the legal system, such as Chang Kyŏng-gŭn and Kim Tu-hŏn, pushed for reforms-or to maintain the direction of reforms underway during the colonial period-that would ensure more equality between the sexes. Those who came of age after liberation, students of Chŏng Kwang-hyŏn, were more open to abolishing the colonial family system altogether for more radically progressive laws. But it was the ardent nationalists like Kim Pyŏng-ro who were so strongly against the colonial legal system that they, quite ironically, left the more feminist reforms to be driven by the lingering rhetoric of colonial reform discourses.

When a public hearing was held for the draft Civil Code, an acute debate broke out between those who wanted to continue the modernizing efforts that the Korean legal system had been undergoing during Japanese colonial rule and those who sought to seize the postcolonial moment to rescind the changes that they considered damaging to Korean cultural identity and to return Korea to a precolonial (and pure) past. Some of the hotly debated issues were "lifting the ban on intralineage marriage," "lifting the ban on nonagnatic adoption," "giving daughters rights to household-head inheritance," and "allowing girls to be adopted (as heirs)." ${ }^{41}$ The Confucian Association castigated such moves and accused those who advocated them of "trying to damage the beautiful customs of our country." ${ }^{2}$

Chŏng Kwang-hyŏn argued that the whole purpose of writing the new Civil Code was to have a set of civil laws that followed the principles of the new constitution. Therefore, any part of the Civil-Code draft that violated the constitution should be abolished. He noted, "We have already implemented land reform in 1949 to liberate tenant farmers. I cannot find any rational reason why we are not yet implementing laws to liberate women to ensure equality between the sexes and men and wives." Lawyer Yi T'ae-yŏng argued that Koreans needed to abolish any family customs that violated the spirit of the constitution. During the public hearing she declared, "[some family customs] might appear to men as good and beautiful customs but from women's perspective these customs and system could be [a source of] resentment bitter to the bones" [ppyŏe samuch'inŭn wŏnhan]; then this good and beautiful custom is not objectively good or beautiful." 43 The audience applauded her statement.

A record of National Assembly Committee hearings relays the high-tension debate over the new Civil Code. On April 8, 1957, the first public hearing for the official draft of the new Civil Code was held. The head of the preparation committee was traditionalist Kim Pyŏng-ro, head of the Supreme Court of Korea 
(Tae'pŏpwon'jang), continuing his push for a restoration of Korean family traditions. In the introductory speech that he gave to the committee, Kim emphasized the need for the new Civil Code to restore Korean traditions, the essence of which was patrilineal descent groups and patriarchal hierarchy. Kim believed the tradition of the patrilineal descent group to be the marker of Korean superiority compared to the Japanese. He denounced the demand for gender equality in family laws, arguing that gender equality should be sought in the society, not in the family. ${ }^{44}$ Kim further denounced the influence of Japanese laws during the colonial period that tainted the great Korean family tradition. With strong words he denounced the "barbaric family culture of the Japanese" that had no regard for patrilineal descent groups. Kim argued that patrilineal descent was not only moral but scientific. He also stated, "if you sought equality between parents and children, and husband and wife, within the family, nothing could be done. Its ill effects would lead to corrosion of morals and ethics and chaos in society." ${ }^{45}$ Not all agreed. The strongest and most vociferous opponent to Kim was Representative Pak Yongjong, a Japan-educated former newspaper reporter, who pointed out that the CivilCode draft violated the gender-equality clause of the Korean Constitution and, in that regard, was inferior even to the new postwar Japanese Civil Code. He even claimed that gender inequality was one of the reasons why Korea was colonized by the Japanese in the first place. ${ }^{46}$

The new Civil Code was promulgated in 1959 and implemented in 1960. It ended, ostensibly, the use of the colonial civil laws that had continued after Korea's liberation from Japanese colonial rule in 1945. While the 1960 Civil Code declared that it implemented the principle of equality of the sexes, many of its codes fell short of this promise. The new Civil Code, according to some evaluations, was "a conciliatory law modeled on the basic principles of the old-fashioned lineage law system [i.e., household-head system] but with an effort to eliminate as much as possible those undemocratic aspects of family life that hampered individual freedoms and the development of individuality." 47 The 1960 Civil Code did advance women's rights on some fronts. Wives now had separate and independent property rights from their husbands, they could sue for divorce on grounds of infidelity (just as their husbands could), and they had full legal capacity in household affairs. ${ }^{48}$ Inheritance rights for widows were strengthened: widows now had full inheritance rights if there was no one else eligible for inheritance (thus, the temporary provision was eliminated), and their share of inheritance was increased from half to equal to the amount of inheritance direct descendants were due. Yet other stipulations preserved the conservative slant that customary laws had in the colonial period. Wives could be divorced for disharmony with parents-in-law (article 840). Although wives had separate-property rights, any property for which ownership was unclear was assumed to be the husband's (article 830, no. 2). Wives were required to live in the husband's household after marriage (article 826, no. 2), and husbands still had the right of guardianship over wives and children (article 
934). A husband did not need to obtain his wife's permission to register a child born out of wedlock in their household register (article 782), while the wife did need such permission. Wives were further disadvantaged in divorce under the 1960 Civil Code. Upon divorce, husbands had precedence over wives for parental rights over children (article 909). Wives did not have the right to ask for a division of household property, nor were they guaranteed alimony. ${ }^{49}$ These stipulations were codifications of the patriarchal aspects of the previous customary laws that strengthened household-head rights and fell well short of the principles of equality between individuals and sexes.

A number of these new codes in Korea were even more conservative than the new Japanese Civil Code. For example, while the Japanese Civil Code assumed common ownership by a married couple of any property that had unclear ownership, the 1960 Korean Civil Code attributed such property to the husband's ownership. Also, while the Japanese Civil Code stipulated that the husband and the wife had shared responsibility to provide for the marital economy, the new Korean Civil Code assumed that the husband provided living expenses for the married couple.

Other parts of the law stipulated even fewer rights for women than during the colonial period. The 1960 Civil Code did not merely inherit the household system of the colonial period but modified it by incorporating the stronger male centricity of the Korean lineage laws, where all male members of the lineage were considered equally valuable in continuing the family line. Under the Japanese laws the main branch of the household and its heir, the eldest son, was privileged in inheritance. Therefore, the separate property of the non-household head was not protected as kazan, the family property, and was equally distributed among all children, daughters as well as sons. But in the Korean Civil Code, all property held by male members of the household was considered family property, and sons were privileged over daughters in all property inheritance. While during the colonial period daughters had equal share with their brothers, in the case with the non-household head's inheritance, under the 1960 Civil Code daughters were due at most half the share of the inheritance received by their brothers. A daughter's share would be one-third that of her eldest brother, the heir to the household headship. If she already had married out of the household, her share shrank to one-fourth of her brothers' shares. In some sense the 1960 Civil Code in Korea expanded the familyproperty concept, while the colonial court had contained it by privileging the main line of a household over branch families. As a result, the inequality between the sexes was strengthened in the postcolonial household-head system in Korea compared to the colonial household system.

\section{SON-IN-LAW ADOPTION REINSTATED}

Among the very few laws that did change in the immediate aftermath of Japan's defeat, the most dramatic shift occurred in son-in-law adoption. Unlike 
Japanese-style family names that were unmistakably recognizable as Japanese and were immediately abolished, the custom of son-in-law adoption was less easily defined as such and had a motley career in the postcolonial Korean civil-law regime. It was first categorically repealed as a Japanese-imposed custom, then reinstated in the new Civil Code of 1960.

Initially, son-in-law adoption was considered one of the quintessential examples of the Japanese distortion and violation of Korean customs, on par with "Japanese-style surnames." A newspaper article in 1949 reported on a Supreme Court (Taebŏbwŏn) decision that nullified son-in-law adoption in South Korea. The article, titled "Sŏyangja nŭn sangsokkwŏn ŏpta, chŏntong sallin taebŏpwŏn sinpan'gyŏllye [Sons-in-law have no inheritance rights, new decision by the Supreme Court that revived tradition]," described a civil case in which a wife had sued her husband for a divorce and nullification of his son-in-law adoption. In the local court, she had won the divorce case but failed to nullify the son-in-law adoption. The Supreme Court overturned this decision and nullified the adoption. The press interpreted this decision as a denial of son-in-law adoption: "The Japanese colonial state, when it was invading [our land], had imported Japanese law in its entirety, ignoring our customs, but the Supreme Court decided to invalidate the law, since it goes against our custom and the beautiful ways of life [mi'p'ung]."50

The Supreme Court reduced the rights of sons-in-law by establishing that (1) sons-in-law cannot become the head of the wife's household, (2) sons-in-law cannot become the adopted sons of the parents-in-law, and (3) sons-in-law do not have inheritance rights to a parent-in-law's property. The decision came long before the details of the new Civil Code were hammered out, but it illustrates how son-in-law adoption could be perceived as a cultural affront in the anticolonial ambience of the early liberation period. With this decision the Supreme Court redefined and overturned what during the 1930s was lauded and advertised as the harbinger of women's inheritance rights.

Son-in-law adoption did not go down in an easy death, as its proponents began pushing for its reinstatement in the new Civil Code. It again appeared as a prominent focus of debate in newspaper reports about the process of drafting a new Civil Code. In 1953, in one of the earliest articles about the new Civil Code, a newspaper reported that "son-in-law adoption at the least would be abolished," betraying some level of anxiety on the part of those who feared that it would not be abolished. ${ }^{51}$ Yet another article a few years later reported that allowing son-in-law adoption was in line with the spirit of abolishing "feudal vestiges" (pong'gŏn chan'jae), by advancing equality between sons and daughters in inheritance..$^{52}$ Adoption laws were one among the few concessions that women's groups achieved, and son-in-law adoption was reinstated. ${ }^{53}$

In newspaper articles introducing and explaining the new Civil Code, marriedin-husband and son-in-law adoption were considered "representative examples of how the new Civil Code confers equal legal rights to women as men." ${ }^{54}$ In a 
newspaper column titled, "14-nyŏn kwa yŏsŏng haebang [Fourteen years (after liberation) and (finally) the liberation of women]," Yi T'ae-yŏng lauded the achievements of the new Civil Code just promulgated in Korea. In an overview Yi laid out the details of the revolutionary changes in family law and concluded that with these changes "women were finally freed from being merely child-bearers [for the husband's family]." ${ }_{55}$ Everything was in fact propagated with the language of gender equality and the trend of the times (sidae $\breve{u} i$ pyŏnhwa), and the new adoption law was evaluated in those terms. What is striking here is the similarity between this rhetoric that associated the expansion of women's rights with sonin-law adoption and the rhetoric of the colonial government in the 1930 s that was utilized to garner support for the 1940 Civil-Ordinances Reform.

Despite the high anticipation about its progressive effects, the hodgepodge nature of the various compromises made in the 1960 new Civil Code meant that son-in-law adoption was more of an idea than an actual new measure that could benefit daughters. A serious catch in the new adoption system was that if the adopted child was not from the agnatic kin group, he could not inherit the household. Therefore, son-in-law adoption was allowed, but with an awkward restraint: an adopted son-in-law could never become the heir to the household headship, and a son-in-law thus also could not become the heir to ancestral rites. This compromise to uphold the lineal laws by restricting inheritance of the household headship and ancestral rites to agnatic kin was probably to appease the traditionalists in Korea. In addition, the 1960 Civil Code also banned adopted sons-in-law from changing their surnames to the wife's surname. The compromise basically disabled the use of son-in-law adoption and daughter household headship and significantly restricted the inheritance rights of daughters.

Most important, the new laws could not resolve the need and desire of Korean families to designate heirs to ancestral rites and the household headship. Even though the newspapers emphasized that "times have changed," customs and beliefs did not change that much; many Koreans still believed in ancestral rites inheritance and saw adoption as usually a resort only for families that needed an heir to ancestral rites. ${ }^{56}$ While the immediate imperative to abolish colonial influences meant that the most apparently Japanese-looking reforms were repudiated, reforms that seemed more neutral and were cloaked in the language of modernity remained intact and had a continuing influence on the direction of reforms into the new Civil Code of 1960. Still, although the discourse of progress toward daughters' inheritance rights that began during the colonial period had a lasting impact on the direction of the reform of family laws after liberation, the new Civil Code failed in many ways to fulfill the promise of modernity for Korean women because the forces of tradition remained strong in practice.

A newspaper legal inquiry section, "Wŏryo ŭngjŏpsil” (Monday salon), in 1958 published a letter from a man in his sixties who was wondering if there were a way he could adopt his son-in-law as his heir. He himself was an only son, as were his 
father and grandfather, and although he had tried with all his might to produce a natural son for an heir, he had failed. The lawyer explained to him that when the new Civil Code was promulgated, he could very well adopt his son-in-law but that this adopted son-in-law, as nonagnatic kin, would be ineligible to become the heir to the ancestral rites. ${ }^{57}$

Son-in-law adoption remained an unattractive option for Korean men for both cultural and practical reasons. The traditional form of adopted son-in-law, teril sawi, was looked down on because it was considered a sign of the man's incompetence and need to depend on his wife's family. An old Korean saying was that if one has only three bushels of coarse barley, one does not become a teril sawi. Although a grandchild from an adopted son-in-law could become the heir, for the grandson to become eligible as heir, the marriage had to have been registered as "married-in husband."

A newspaper article from November 19, 1965, titled, "Ddak'han munam dong'nyŏ" (Pathetic only daughter) relays a story about a mother of three who sent an appeal letter to the family court in Seoul about her predicament as an only child. Since her natal family was in danger of being "discontinued" (chŏlga), and her husband was unwilling to leave his house for her house, she was considering getting a divorce to marry another man willing to marry into her family (ippu honin). To this the judge who answered her query agreed that son-in-law adoption was practically unrealizable in Korea "because of a [culture that emphasizes] men's face," meaning it would be too demeaning for the husband to become an adopted son-in-law. He sympathized with the woman's situation and agreed that family law should be revised to implement "same surnames for married couples." Another article a few days later reintroduced this letter but emphasized the judge's advice that the woman's decision to get a divorce to continue her natal family was an "extremely dangerous thought" (wihŏm chŏnmanhan saeng'gak). ${ }^{58}$ If the husband was unwilling to become an adopted son-in-law-and such a decision indeed was understandable, it was implied, as son-in-law adoption would scar the husband's pride-the judge advised that the woman had the option to arrange a posthumous adoption for her father. The article then provided information about the procedure in detail, probably to educate the readers challenged with the same issue.

\section{CONCLUSION}

Contrary to state propaganda, the 1940 Civil-Ordinances Reform neither abolished discrimination nor granted equal rights to colonized Koreans. Instead, it attempted to strengthen the household system by naturalizing it with the new name system and continuing the reform discourses to expand daughters' inheritance rights. From the perspective of women's and family issues, what is remarkable about the reform was not its conspicuous break from the past as a drastic assimilatory measure but its continued policy toward reform in the inheritance 
regime. Reform discourses that continued into the 1940s left a long and strong legacy in postcolonial Korea. Examination of civil cases after the 1945 independence and the 1960 new Civil Code shows that the legacy of the colonial customary laws lived on in Korea. Even though the postcolonial period brought a broad abolishment of Japanese legacies, the household system, with its strong patriarchal rights, was slow to be identified as one of those legacies. Although the purpose of strengthening the rights of the household head supposedly was to dismantle the Korean lineage system, rather ironically, household-head rights came to be accepted as a Korean tradition rather than a Japanese import. 